\title{
Motivasi Belajar Ditinjau Dari Iklim Kelas Pada Siswa/Siswi Jurusan IPS
}

\author{
Cindy Wiliem, Sri Hartini, Diny Atrizka \\ Universitas Prima Indonesia, Indonesia \\ Cindywiliem17@gmail.com
}

\begin{abstract}
The purpose of this research is to determine the relationship between classroom climate and learning motivation. The hypothesis submitted in this research is, there is a positive relationship between classroom climate and learning motivation, with assumption the more conducive classroom climate perceived by students, the higher learning motivation of students and vice versa. The research subjects used in this study were high school students in Methodist 2 with a major of Social Sciences as many as 182 people selected by the disproportionate stratified random sampling method. The method of analysis data used for this research is Product Moment correlation through SPSS 17 for Windows. The results of data analysis showed $r=0.575$ and $p=0.000(p<0.05)$ which means that there is a positive relationship between classroom climate and learning motivation. The results of this research show that the contribution (R2) given the classroom climate variable to learning motivation was 33.1 percent, the rest 66.9 percent was influenced by other factors not examined in this research. From the results of this research it can be concluded that the research hypothesis there is a positive relationship between classroom climate with learning motivation, can be accepted.
\end{abstract}

Keywords: Classroom Climate; Learning Motivation; Students

\begin{abstract}
ABSTRAK
Penelitian ini bertujuan untuk mengetahui hubungan antara iklim kelas dan motivasi belajar. Hipotesis yang diajukan dalam penelitian ini adalah bahwa ada hubungan positif antara iklim kelas dan motivasi belajar, dengan asumsi iklim kelas yang lebih kondusif dirasakan oleh siswa, semakin tinggi motivasi belajar siswa dan sebaliknya. Subjek penelitian yang digunakan dalam penelitian ini adalah siswa/i SMA di Methodist 2 dengan jurusan IPS sebanyak 182 orang yang dipilih dengan metode disproportionate stratified random sampling. Analisis data yang digunakan adalah dengan menggunakan korelasi Product Moment melalui SPSS 17 untuk Windows. Hasil analisis data menunjukkan $r=0,575$ dan $\mathrm{p}=0,000(\mathrm{p}<0,05)$ yang menunjukkan bahwa ada hubungan positif antara iklim kelas dan motivasi belajar. Hasil penelitian ini menunjukkan bahwa kontribusi (R2) yang diberikan variabel iklim kelas terhadap motivasi belajar adalah 33,1 persen, sisanya 66,9 persen dipengaruhi oleh faktor lain yang tidak diteliti. Dari hasil penelitian ini dapat disimpulkan bahwa hipotesis penelitian ada hubungan positif antara iklim kelas dengan motivasi belajar, dapat diterima.
\end{abstract}

Kata kunci: Iklim Kelas; Motivasi Belajar; Siswa

\section{Pendahuluan}

Pendidikan merupakan salah satu aspek kehidupan yang sangat penting bagi setiap individu, terutama bagi peserta didik. Dengan adanya pendidikan peserta didik diharapkan mampu untuk mengembangkan diri dan bepikir kritis. Untuk mampu mengembangkan diri dan berpikir kritis, diperlukan keasadaran diri dari setiap peserta didik akan tujuan pendidikan itu sendiri.

Sekolah merupakan suatu tempat dimana tujuan-tujuan tersebut dapat tercapai. Di sekolah juga terjadi suatu proses pendidikan formal, dikatakan formal karena di sekolah terselenggara berbagai macam kegiatan yang telah direncanakan termasuk kegiatan proses belajar dan mengajar di dalam kelas. Peserta didik adalah subjek utama dalam pendidikan. Siswa atau peserta didik dalam proses belajar mengajar sebagai pihak yang ingin meraih cita-cita, memiliki tujuan dan kemudian ingin mencapainya secara optimal. Oleh karena itu Sardiman (2016) menyatakan bahwa siswa atau peserta didik merupakan subjek belajar bukan objek belajar (dalam proses belajar mengajar).

Pada proses pendidikan itu sendiri, kegiatan yang paling utama bagi para peserta didik adalah belajar. Slamento (dalam Wahab, 2016) menyatakan bahwa belajar adalah suatu proses usaha yang 
dilakukan individu untuk memperoleh suatu perubahan tingkah laku yang baru secara keseluruhan, sebagai hasil pengalaman individu itu sendiri dalam interaksi dengan lingkungannya. Belajar sangat penting bagi setiap individu terutama sebagai peserta didik. Namun belajar juga tidak selalu menyenangkan bagi beberapa peserta didik sehingga terdapat siswa yang melakukan beberapa hal-hal yang tidak semestinya seperti bolos dari sekolah.

Terdapat beberapa kasus mengenai siswa yang melakukan bolos sekolah, salah satunya yaitu tujuh pelajar yang melakukan bolos sekolah dan pergi bermain di warnet yang terletak di Sukmajaya, Depok. Ketujuh pelajar tersebut terjaring razia satpol Pamong Praja (PP). Mereka kedapatan sedang bermain game online di salah satu warnet di Sukmajaya, Depok, di jam sekolah mengenakan baju sekolah (tribunnews.com).

Masalah belajar merupakan masalah yang paling aktual dihadapi setiap orang terutama bagi peserta didik. Salah satu masalahnya adalah kurangnya semangat dalam belajar. Berdasarkan hasil wawancara yang dilakukan oleh peneliti dengan guru di Methodist-2, diketahui bahwa siswa/siswi yang kurang semangat dalam mengikuti pelajaran adalah siswa/siswi dengan jurusan IPS. Oleh karena itu, peneliti mewawancarai beberapa siswa SMA Methodist-2 khususnya dengan jurusan IPS. Berdasarkan hasil wawancara diketahui bahwa para siswa sering bolos sekolah setidaknya dua kali dalam satu minggu. Selain itu para murid juga sering mengerjakan pekerjaan rumah mereka di sekolah pada hari ketika akan dikumpulkan. Pada saat guru menjelaskan pelajaran para murid juga berbicara dengan teman lainnya dan tidak memperhatikan apa yang diajarkan oleh gurunya. Para murid juga tidak aktif didalam proses belajar mengajar, maksudnya adalah tidak banyak murid yang mau bertanya tentang apa yang telah dipelajari.

Menurut (Santrock, 2013) menyatakan bahwa murid yang tidak memiliki motivasi tidak akan berusaha keras untuk belajar, sedangkan murid yang bermotivasi tinggi senang ke sekolah dan menyerap proses belajar. Kehadiran faktor-faktor psikologis dalam belajar akan memberikan andil yang cukup penting. Staton (dalam Sardiman, 2016) menguraikan enam jenis faktor psikologis itu, yaitu adalah motivasi, konsentrasi, reaksi, organisasi, pemahaman dan ulangan.

Maslow (dalam Setiawan, 2017) menyebutkan motivasi belajar adalah suatu dorongan internal dan eksternal yang menyebabkan seseorang atau individu untuk bertindak atau mencapai tujuan, sehingga perubahan tingkah laku pada diri peserta didik diharapkan terjadi. Sejalan dengan pendapat Maslow, Sardiman (2016) menjelaskan motivasi belajar adalah seluruh daya penggerak didalam diri siswa yang menimbulkan kegiatan belajar yang menjamin kelangsungan dari kegiatan belajar yang memberikan arah pada kegiatan belajar sehingga tujuan yang dikehendaki oleh subjek belajar itu dapat dicapai.

Selain itu Widiasworo (2017) mendefinisikan motivasi belajar adalah keseluruhan daya penggerak dalam diri peserta didik yang menimbulkan kegiatan belajar, yang menjamin kelangsungan dari kegiatan belajar dan memberikan arah pada kegiatan belajar, sehingga tujuan yang dikehendaki oleh peserta didik tercapai. Adapun fungsi motivasi dalam belajar menurut Mosely (dalam Khodijah, 2014) fungsi adalah mendorong manusia untuk berbuat, menentukan arah perbuatan, yaitu kearah tujuan yang hendak dicapai, dan Menyeleksi perbuatan.

Uno (2017) menyatakan bahwa motivasi belajar dapat timbul karena faktor intrinsik, berupa hasrat dan keinginan berhasil dan dorongan kebutuhan belajar, harapan akan cita-cita. Sedangkan faktor ekstrinsiknya adalah adanya penghargaan, lingkungan belajar yang kondusif dan kegiatan belajar yang menarik. Salah satu faktor ekstrinsik yang mempengaruhi motivasi belajar adalah lingkungan yang kondusif. Sardiman (2016) mengemukakan lingkungan tersebut termasuk lingkungan dalam kelas yang dapat disebut juga sebagai iklim kelas.

Penelitian yang dilakukan Hadinata (2009) membuktikan bahwa iklim kelas memberikan kontribusi yang signifikan terhadap motivasi belajar siswa. Hal tersebut sesuai dengan pernyataan Kauchak dan Eggen (dalam Hadinata, 2009) yang menyatakan bahwa iklim kelas adalah hal yang penting karena menciptakan suatu lingkungan yang memberikan dorongan terhadap motivasi dan juga berprestasi. Menurut Hadiyanto (2016) iklim kelas adalah segala situasi yang muncul akibat hubungan antara pendidik dan peserta didik atau hubungan antar-peserta didik yang menjadi ciri khusus dari kelas dan mempengaruhi proses belajar dan mengajar. Borich (dalam Muijs \& Reynolds, 2008) 
mendefinisikan tiga tipe iklim kelas yang dapat digunakan, yakni tipe kompetitif, tipe kooperatif, dan tipe individualistik

Peneliti tertarik untuk mencari hubungan iklim kelas dengan motivasi belajar pada siswa/siswi yang mengambil jurusan IPS. Siswa/siswi yang mengambil jurusan IPS sering dianggap memiliki motivasi belajar yang rendah, dimana siswa/siswi tersebut juga yang biasa sering membuat keributan atau masalah dalam kelas sehingga iklim kelas menjadi kurang kondusif. Iklim kelas yang kurang kondusif tersebut memicu turunnya motivasi belajar murid.

Penelitian terdahulu oleh Venora dan Izzati (2008) terhadap 137 siswa telah membuktikan adanya hubungan antara iklim kelas dengan motivasi belajar. Dengan pengertian semakin kondusif iklim kelas yang dipersepsi oleh siswa maka semakin tinggi motivasi belajar siswa, dan sebaliknya. Iklim kelas yang bersifat positif akan menimbulkan ketertarikan siswa untuk melakukan kegiatan belajar. Ketertarikan siswa saat pada proses pembelajaran dapat menimbulkan motivasi belajar dalam diri siswa. Motivasi tersebut akan mendorong siswa untuk melakukan upaya-upaya yang optimal dan menuntun siswa untuk selalu berusaha dalam belajar.

Berdasarkan uraian-uraian sebelumnya, maka peneliti tertarik untuk meneliti hubungan antara iklim kelas dengan motivasi belajar pada siswa/siswi SMA Methodist-2 dengan jurusan IPS di Medan. Tujuan dari penelitian ini untuk mengetahui hubungan antara iklim kelas dengan motivasi belajar. Manfaat praktis yang diharapkan dari penelitian ini jika hipotesis diterima adalah bagi siswa Memberikan pemahaman dan pengetahuan mengenai pentingnya motivasi belajar dengan suasana lingkungan belajar yang kondusif dan bagi sekolah yaitu memberikan informasi mengenai gambaran yang jelas tentang iklim kelas dan motivasi belajar siswa yang ada di sekolah, sehingga dapat memperbaiki dan meningkatkan sistem pembelajaran di kelas. Hipotesis yang diajukan dalam penelitian ini adalah terdapat hubungan positif antara iklim kelas dengan motivasi belajar. Dengan asumsi semakin kondusif iklim kelas, maka semakin tinggi motivasi belajar siswa. Sebaliknya semakin tidak kondusif iklim kelas, maka semakin rendah motivasi belajar.

\section{Metode Penelitian}

\section{Variable Penelitian}

Variabel terikat dalam penelitian ini adalah motivasi belajar, sedangkan variabel bebas adalah iklim kelas.

\section{Subjek Penelitian}

Populasi dalam penelitian ini sebanyak 379 siswa-siswi SMA yang mengambil jurusan IPS di Methodist-2 Medan. Dengan jumlah populasi sebesar 379 siswa-siswi, maka penelitian ini menggunakan teknik Disproportionate stratified random sampling dengan menggunakan tabel Issac dan Michael dengan tingkat kesalahan 5\%, maka sampel yang digunakan berjumlah 182 siswa-siswi.

\section{Metode Pengumpulan Data}

Teknik pengumpulan data yang digunakan dalam penelitian ini dengan menggunakan metode pembagian questioner untuk mengukur motivasi belajar dan iklim kelas. Jenis skala yang digunakan dalam penelitian ini adalah skala Likert. Penelitian ini menggunakan skala Likert yang merujuk pada indikator motivasi belajar yang diuraikan oleh Uno (2017), yaitu: adanya hasrat dan keinginan berhasil, adanya dorongan dan kebutuhan dalam belajar, adanya penghargaan dalam belajar, adanya harapan dan cita-cita masa depan, adanya kegiatan yang menarik dalam belajar, dan adanya lingkungan belajar yang kondusif, sehingga memungkinkan seorang siswa dapat belajar dengan baik. Skala ini terdiri dari 48 butir pernyataan, dengan 24 butir pernyataan favourable dan 24 butir pernyataan unfavourable. Dengan daya gerak dari 0,310-0,674 dengan estimasi reliabilitas Alpha sebesar 0,902.

Skala iklim kelas yang digunakan dalam penelitian ini adalah dimensi iklim kelas yang dikemukakan oleh Lopez, dkk., (2018), yang diantaranya : peer relationship (hubungan teman sebaya), teacher-student interactions (interaksi antara guru dan siswa), teachers' orientation towards learning (orientasi guru terhadap pembelajaran), dan physical environment (lingkungan fisik). Yang terdiri dari 
40 butir pernyataan, dengan 20 butir pernyataan favourable dan 20 butir pernyataan unfavourable. Dengan daya gerak dari 0,345-0,555 dengan estimasi reliabilitas Alpha sebesar 0,899.

Teknik analisis yang digunakan untuk menguji hipotesis sekaligus menganalisis data hasil penelitian ini adalah dengan menggunakan metode korelasi Product Moment (Pearson Corellation).

\section{Hasil Dan Pembahasan}

Sebelum melakukan uji hipotesis, terlebih dahulu dilakukan uji asumsi untuk mengetahui ada tidaknya penyimpangan data yang diperoleh dari alat pengumpulan data. Uji asumsi yang digunakan dalam penelitian ini adalah uji normalitas dan uji linieritas.

Tabel 1. Hasil Uji Normalitas

\begin{tabular}{cccccc} 
Variabel & SD & K-SZ & Sig. & P & Keterangan \\
\hline Motivasi Belajar & 9,324 & 1,033 & 0,1199 & $\mathrm{P}>0,05$ & Sebaran normal \\
\hline Iklim Kelas & 8,580 & 0,801 & 0,271 & $\mathrm{P}>0,05$ & Sebaran normal
\end{tabular}

Uji normalitas dilakukan untuk dapat mengetahui apakah variabel penelitian telah menyebar secara normal. Uji normalitas sebaran menggunakan uji Kolmogorov Smirnov Test (K-SZ). Data dikatakan berdistribusi normal jika $\mathrm{p}>0,05$ (Priyatno, 2011). Variabel motivasi belajar menunjukkan nilai KSZ sebesar 1,0331 dengan Sig sebesar 0,238 untuk uji 2 (dua) ekor / Sig. 2-tailed, sedangkan penelitian ini memiliki hipotesis satu arah, sehingga yang dipakai adalah uji 1 (satu) ekor / Sig. 1-tailed sebesar $0,119$ ( $p>0,05)$ artinya sebaran skor motivasi belajar mengikuti distribusi normal. Variabel iklim kelas menunjukkan nilai K-SZ sebesar 0,801 dengan Sig sebesar 0,543 untuk uji 2 (dua) ekor / Sig 2-tailed, dan untuk Sig. 1-tailed sebesar 0,271 ( $\mathrm{p}>0,05)$ artinya sebaran skor iklim kelas mengikuti distribusi normal. Berdasarkan hasil tersebut variabel motivasi belajar dan iklim kelas memiliki sebaran atau berdistribusi normal karena $\mathrm{p}>0,05$.

Tabel 2. Hasil uji Linearitas

\begin{tabular}{cccc} 
Variabel & F & P & Keterangan \\
\hline $\begin{array}{c}\text { Motivasi Belajar } \\
\text { Iklim Kelas }\end{array}$ & 94.948 & 0,000 & Linear $(\mathrm{P}<0,05)$
\end{tabular}

Berdasarkan Tabel 2 dapat dilihat bahwa variabel motivasi berprestasi dan iklim kelas memiliki hubungan linear. Hal ini dapat dilihat dari nilai $P$ yang diperoleh yaitu 0,000 . Artinya $p<0,05$ maka dapat disimpulkan kedua variabel memiliki hubungan linear dan telah memenuhi syarat untuk dilakukan analisa korelasi Product Moment.

Setelah uji asumsi diterima, selanjutnya dilakukan uji hipotesis. Pengujian hipotesis dilakukan dengan menggunakan analisis Pearson Correlation. Hasil uji statistik dapat dilihat pada Tabel 3.

Tabel 3. Hasil Uji Hipotesis

\begin{tabular}{ccc} 
Analisis & Pearson Correlation & Signifikansi (p) \\
\hline Korelasi & 0,575 & 0,000
\end{tabular}

Berdasarkan hasil analisis korelasi antara motivasi belajar dengan iklim kelas, diperoleh koefisien korelasi product moment sebesar 0,575 dengan $\mathrm{p}=0,000$ ( $\mathrm{p}<0,05$ : Sig. 1-tailed). Hal ini menunjukkan bahwa adanya korelasi positif antara iklim kelas dengan motivasi belajar. Dari hasil perhitungan tersebut, maka hipotesis yang diajukan pada penelitian ini menunjukkan terdapat hubungan positif antara iklim kelas dengan motivasi belajar dinyatakan dapat diterima.

Tabel 4. Sumbangan Efektif 


\begin{tabular}{lrrrr} 
Model & R & R Square & $\begin{array}{c}\text { Adjusted R } \\
\text { Square }\end{array}$ & $\begin{array}{c}\text { Std. Error of } \\
\text { the Estimate }\end{array}$ \\
\hline 1 & $.575^{\text {a }}$ & .331 & .327 & 7.650
\end{tabular}

Berdasarkan tabel 4 sumbangan efektif di atas, dapat disimpulkan pada penelitian ini diperoleh koefisien determinasi sebesar 0,331. Dapat disimpulkan bahwa sumbangan 33,1 persen iklim kelas mempengaruhi motivasi belajar dan selebihnya 66,9 persen dipengaruhi faktor-faktor lain yang tidak diteliti pada penelitian ini.

Tabel 5. Perbandingan Data Mean Empirik dan Hiptetik

\begin{tabular}{|c|c|c|c|c|c|c|c|c|}
\hline \multirow{2}{*}{$\begin{array}{c}\text { Variabel } \\
\text { Iklim }\end{array}$} & \multicolumn{3}{|c|}{ Empirik } & \multirow{2}{*}{ SD } & \multicolumn{3}{|c|}{ Hipotetik } & \multirow{2}{*}{ SD } \\
\hline & Min & $\operatorname{Max}$ & Mean & & Min & Max & Mean & \\
\hline Kelas & 76 & 116 & 98,21 & 8,580 & 31 & 124 & 77,5 & 15,5 \\
\hline $\begin{array}{l}\text { Motivasi } \\
\text { Belajar }\end{array}$ & 70 & 108 & 88,09 & 9,324 & 35 & 140 & 87,5 & 17,5 \\
\hline
\end{tabular}

Hasil analisis untuk skala iklim kelas diperoleh mean empirik > mean hipotetik yaitu 98,21 > 77,5 maka dapat disimpulkan bahwa iklim kelas yang dirasakan oleh subjek penelitian dapat dikategorikan tinggi atau kondusif. Hasil analisis untuk skala motivasi belajar diperoleh mean empirik < mean hipotetik yaitu 88,09 > 87,5 maka dapat disimpulkan bahwa motivasi belajar pada subjek penelitian lebih tinggi daripada populasi pada umumnya.

Tabel 6. Kategorisasi Data Motivasi Belajar

\begin{tabular}{lcccc}
\multicolumn{1}{c}{ Variabel } & Rentang Nilai & Kategori & Jumlah (n) & Persentase \\
\hline \multirow{2}{*}{$\begin{array}{c}\text { Motivasi } \\
\text { Belajar }\end{array}$} & $\mathrm{x}<70$ & Rendah & 0 & $0 \%$ \\
\cline { 2 - 5 } & $70 \leq \mathrm{x}<105$ & Sedang & 165 & $90,66 \%$ \\
\hline & $\mathrm{x} \geq 105$ & Tinggi & 17 & $9,34 \%$ \\
\hline & Jumlah & & 182 & 100
\end{tabular}

Berdasarkan Tabel 6 dapat dilihat bahwa subjek motivasi belajar pada kategori rendah berjumlah 0 orang dengan persentase 0 persen, kategori sedang berjumlah 165 orang dengan persentase sebesar 90,66 persen sedangkan subjek motivasi belajar yang masuk dalam kategori tinggi berjumlah 17 orang dengan persentase sebesar 9,34 persen. maka dapat disimpulkan bahwa tidak ada subjek yang memiliki motivasi belajar rendah, seluruh subjek memiliki motivasi berprestasi yang dikategorikan sedang dan tinggi.

Tabel 7. Kategorisasi Data Iklim Kelas

\begin{tabular}{ccccc} 
Variabel & Rentang Nilai & Kategori & Jumlah (n) & Persentase \\
\hline \multirow{3}{*}{ Iklim Kelas } & $\mathrm{x}<62$ & Rendah & 0 & $0 \%$ \\
\cline { 2 - 5 } & $62 \leq \mathrm{x}<93$ & Sedang & 44 & $24,18 \%$ \\
\cline { 2 - 5 } & $\mathrm{x} \geq 93$ & Tinggi & 138 & $75,82 \%$ \\
\hline & Jumlah & & 182 & $100 \%$
\end{tabular}

Berdasarkan kategori pada tabel 7, maka dapat dilihat iklim kelas yang dirasakan pada subjek yang masuk dalam kategori rendah berjumlah 0 persen, kategori sedang berjumlah 44 orang dengan persentase sebesar 24,18 persen sedangkan subjek dengan iklim kelas yang masuk dalam kategori tinggi berjumlah 138 orang dengan persentase sebesar 75,82 persen. maka dapat disimpulkan bahwa tidak ada subjek yang memiliki skor iklim kelas yang rendah, seluruh subjek merasakan iklim kelas yang dikategorikan sedang dan tinggi.

Penelitian ini menunjukkan rata-rata siswa di SMA Methodist 2 Jurusan IPS merasakan iklim kelas yang tinggi atau kondusif dapat terlihat dari data penelitian terdapat 138 siswa dengan persentase 75,82 
persen berada pada kategori tinggi, kemudian 44 siswa merasakan iklim kelas yang sedang dengan persentase sebesar 24,18 persen.

Berdasarkan hasil observasi dan wawancara terhadap siswa/siswi di SMA Methodist 2 Medan jurusan IPS menunjukkan iklim kelas yang tinggi, yaitu sebanyak 138 orang dengan persentase 75,82 persen. Meskipun berada dalam lingkungan dengan mayoritas murid beretnis tionghua, siswa dapat membaur dengan baik dengan murid yang beretnis lain tanpa melihat suku, bahasa maupun status sosial. Pernyataan diatas sesuai dengan salah satu dimensi dari iklim kelas yaitu hubungan teman sebaya. Dimensi lain dari iklim kelas yang dapat terlihat ketika peneliti melakukan penelitian di SMA Methodist 2 yaitu interaksi antara guru dan siswa. Hal ini dapat dilihat ketika pada saat proses belajar mengajar. Guru sering bertanya kepada murid dan juga peneliti melihat ada guru yang menjelaskan langsung kepada murid yang belum mengerti. Namun, ada beberapa guru yang mengajar dimana guru tersebut jarang bertanya kepada murid-muridnya, sehingga para murid merasa bosan dan mengantuk.

Penelitian ini menunjukkan rata-rata siswa di SMA Methodist 2 dengan jurusan IPS memiliki motivasi belajar yang sedang. dapat terlihat dari data penelitian terdapat 165 siswa dengan persentase 90,66 persen berada pada kategori sedang kemudian 17 siswa dikategorikan memiliki konsep diri tinggi dengan persentase sebesar 9,34 persen dan tidak terdapat siswa yang memiliki motivasi belajar yang rendah dengan persentase 0 persen. Berdasarkan penjelasan diatas dapat disimpulkan rata-rata siswa di SMA Methodist 2 dengan jurusan IPS memiliki motivasi belajar yang sedang.

Berdasarkan hasil observasi dan wawancara menunjukkan motivasi belajar yang sedang dengan persentase 90,66 persen terlihat dari indikator adanya hasrat dan keinginan untuk belajar. Para murid menyatakan bahwa mereka hanya membaca kembali beberapa pelajaran yang menurut mereka penting. Hal ini menunjukkan bahwa para murid memiliki hasrat dan keinginan untuk berhasil walaupun hanya pada beberapa pelajaran saja. Hal lain yang mewakili indikator dari motivasi belajar yaitu adanya harapan dan cita-cita masa depan. Pada saat peneliti mewawancarai Para murid, mereka menyadari bahwa belajar itu penting bagi masa depan mereka, Namun, terkadang ada ajakan dari teman untuk bolos sekolah dan pergi ke warung internet, atau terlambat masuk ke sekolah sampai jam pelajaran kedua atau ketiga, sehingga dihukum oleh guru BP. Hal tersebut menunjukkan bahwa para murid sebenarnya mengerti bahwa belajar itu penting bagi diri mereka. Namun, karena mereka mudah terpengaruhi oleh lingkungan, maka mereka terkadang bolos sekolah agar bisa diterima oleh lingkungan atau komunitasnya.

Hasil penelitian pada 182 siswa-siswi SMA Methodist 2 Medan yang menjadi subjek penelitian diperoleh hasil bahwa ada hubungan positif antara iklim kelas dengan motivasi belajar dengan koefisien korelasi product moment sebesar $r=0,575$ nilai $p$ sebesar $0,000(p<0,05)$, artinya semakin kondusif iklim kelas yang dirasakan seseorang maka motivasi belajar semakin tinggi, dan sebaliknya semakin tidak kondusif iklim kelas maka semakin rendah motivasi belajar.

Hasil penelitian ini didukung oleh pendapat Hadiyanto (2016) yang menyatakan iklim kelas merupakan kualitas lingkungan kelas yang terus menerus dialami oleh guru yang mempengaruhi tingkah laku siswa dalam menciptakan proses pembelajaran yang kondusif. Iklim kelas yang kondusif akan mendorong dan menguatkan motivasi belajar pada siswa. Suasana kelas yang nyaman dan edukatif siswa akan merasa betah belajar di kelas, tidak cepat merasa jenuh dan membuat peserta didik bersemangat dan termotivasi untuk belajar.

Hasil penelitian ini senada dengan penelitian terdahulu yang dilakukan oleh peneliti sebelumnya Nasution dan Syaf (2018) pada siswa SMK Abdurrab dengan jumlah 56 orang menunjukkan hasil bahwa ada hubungan positif antara iklim kelas dengan motivasi belajar siswa SMK Abdurarab, Pekanbaru kelas X,XI dan XII. Suasana yang menyenangkan yang dirasakan oleh murid-murid memberi kemungkinan anak dapat memusatkan perhatian dalam belajar.

\section{Kesimpulan}

Berdasarkan hasil penelitian, dapat disimpulkan bahwa terdapat hubungan positif antara iklim kelas dengan motivasi belajar pada siswa/siswi jurusan IPS Methodist-2 Medan dengan korelasi product moment $(\mathrm{r})$ sebesar 0,575 dengan $\mathrm{p}$ sebesar $0,000(\mathrm{p}<0,05)$, artinya semakin kondusif iklim kelas yang dirasakan siswa, maka semakin tinggi motivasi belajar, dan sebaliknya jika semakin tidak kondusif iklim kelas yang dirasakan siswa maka semakin rendah motivasi belajar siswa. Hasil penelitian ini menunjukkan bahwa sumbangan yang diberikan variabel iklim kelas terhadap variabel motivasi belajar 
adalah sebesar 33,1 persen, selebihnya 66,9 persen dipengaruhi oleh faktor lain yang tidak diteliti, seperti penyesuaian diri dan perhatian orangtua.

\section{Daftar Pustaka}

Hadinata, P. (2009). Iklim Kelas dan Motivasi Belajar Siswa SMA. Jurnal Psikologi, Vol.3 No.1: 93 98. Diakses pada tanggal 4 juni 2018 dari : https://anzdoc.com/download/iklim-kelas-danmotivasi-belajar-siswa-sma.html

Hadiyanto. (2016). Teori dan Pengembangan Iklim Kelas dan Iklim Sekolah. Jakarta : Kencana.

Khodijah, N. (2014). Psikologi Belajar. Palembang : IAIN Raden Patah Press.

Lopez, V., Vallejos, J. T., Ascorra, P., Parada, B. V., Bilbao, M., \& Valdes, R. (2018). Construction and validation of a classroom climate scale: a mixed methods approach. Learning Environment Research, Vol. 21 No. 3: 407-422. Diakses pada tanggal 9 November 2018 dari https://link. springer.com/article/10.1007/s10984-018-9258-0.

Muijs, D \& Reynolds, D. (2008). Effective Teaching (Teori dan Aplikasi). Yogyakarta : Pustaka Belajar.

Nasution, I. N. \& Syaf, A. (2018). Hubungan Iklim Kelas dengan Motivasi Belajar Siswa SMK Abdurrab. Psikologi, Vol.1 No.2: 98-109. Diakses pada tanggal 11 Oktober 2018 dari : http://jurnal.univrab.ac.id/index.php/psi/article/view/528/354.

Priyatno, D. (2011). SPSS: Paham Analisa Statistik Data dengan SPSS. Yogyakarta : Mediakom.

Santrock, J. W. (2013). Psikologi Pendidikan Edisi Kedua. Jakarta : Kencana

Sardiman, A. M. (2016). Interaksi dan Motivasi Belajar Mengajar. Bandung : Rajawali Pers.

Setiawan, M. A. (2017). Belajar dan Pembelajaran. Ponorogo : Uwais Inspirasi Indonesia.

Uno, H. B. (2017). Teori Motivasi dan Pengukurannya. Jakarta : PT. Bumi Aksara.

Venora, D. \& Izzati, U. A. (2008). Hubungan Antara Persepsi Terhadap Iklim Kelas dengan Motivasi Belajar Siswa Kelas XI IPS di SMA X Kota Surabaya. Jurnal Psikologi Pendidikan, Vol.5 No.1: 1-5. Diakses pada tanggal 19 Juni 2018 dari : http://jurnalmahasiswa.unesa.ac.id/index.php/character/article/view/22695

Wahab, R. (2016). Psikologi Belajar. Jakarta : PT. RajaGrafindo Persada.

Widiasworo, E. (2017). Masalah-masalah Peserta Didik dalam Kelas dan Solusinya. Yogyakarta : Araska

Tribunnews, Depok. (2018). Sebanyak 7 Pelajar Bolos Sekolah di Warnet, Terjaring Razia Satpol PP Depok. Diakses pada tanggal 18 Juni 2018 dari: http://wartakota.tribunnews.com/2018/03/15/sebanyak-7-pelajar-bolos-sekolah-di-warnetterjaring-razia-satpol-pp-depok 